УДК 582.284.99/502.72(597)

\title{
The first data on wood-inhabiting fungi (Basidiomycota) of the Con Dao Archipelago (South Vietnam)
}

\author{
N. V. Bukharova ${ }^{1 *}$, L. A. Prozorova ${ }^{1}$, X. Q. Ngo ${ }^{2,3}$ \\ ${ }^{1}$ Federal Scientific Center of the East Asian Terrestrial Biodiversity, Far Eastern Branch of the Russian Academy of Sciences, \\ Pr-t 100-letiya Vladivostoka 159, Vladivostok,690022, Russian Federation.E-mail: Nadya808080@mail.ru* \\ ${ }^{2}$ Institute of Tropical Biology, Vietnam Academy of Science and Technology, Tran Quoc Toan Str. 85, Ho Chi Minh City, Vietnam \\ ${ }^{3}$ Graduate University of Science and Technology, Vietnam Academy of Science and Technology, \\ 18 Hoang Quoc Viet, Ha Noi, Vietnam \\ *Corresponding author
}

Keywords: biodiversity, mycological research, polypores, tropical fungi, South-East Asia, South Vietnam.

Summary. The first data on wood-inhabiting fungi from the oceanic Con Dao Islands are given. Illustrated checklist of fungi collected on the two largest islands of the archipelago Con Son and Bay Canh is provided. The list includes nine species of wood decaying polyporoid and corticioid fungi from eight genera in four families - Antrodiella serpula, Daedaleopsis nitida, Skeletocutis nivea, Cellulariella acuta, Microporus xanthopus, Laetiporus sulphureus, Hymenochaete rubiginosa, Phellinus fastuosus, P. gilvus. Six species are widely distributed from Boreal to Tropic and other three are of tropical and subtropical distribution. The first three species are new for the Vietnam. Both ecological and medicine importance of fungi recorded are discussed.

\section{Первые сведения о деревообитающих грибах (Basidiomycota) архипелага Кондао (южный Вьетнам)}

\author{
Н. В. Бухарова ${ }^{1}$, Л. А. Прозорова ${ }^{1}$, К. К. Нго ${ }^{2,3}$ \\ ${ }^{1}$ Федеральный научный цеентр биоразнообразия наземной биоты Восточной Азии ДВО РАН, \\ пр-т 100-летия Владивостока 159, г. Владивосток, 690022, Россия \\ ${ }^{2}$ Институт тропической биологии, Вьетнамская академия науки и технологии, \\ ул. Тран Куок Тоан, 85, г. Хотимин, Вьетнам \\ ${ }^{3}$ Университет науки и технологии, Вьетнамская академия науки и технологии, \\ ул. Хоан Куок Вьет, 18t, г. Ханой, Вьетнам
}

Ключевые слова: биоразнообразие, микологические исследования, полипоровые грибы, тропические грибы, Юго-Восточная Азия, Южный Вьетнам.

Аннотация. В статье даны первые сведения о деревообитающих грибах океанических островов Кондао. Представлен иллюстрированный список грибов, собранных с валежных стволов и ветвей лиственных пород деревьев на двух крупнейших островах архипелага Консон и Бэйкан. Список включает девять видов дереворазрушающих полипороидных и кортициоидных грибов из восьми родов и четырех семейств - Antrodiella serpula, Daedaleopsis nitida, Skeletocutis nivea, Cellulariella acuta, Microporus xanthopus, Laetiporus sulphureus, Hymenochaete rubiginosa, Phellinus fastuosus, P. gilvus. Три первых вида грибов впервые упоминаются для Вьетнама. Шесть видов широко распространены от умеренной до тропической зоны, а остальные три встречаются в тропиках и субтропиках. Обсуждается экологическое и медицинское значение найденных видов. 


\section{Introduction}

The Con Dao Archipelago is one of the southern territories of Vietnam. The Archipelago is located about $80 \mathrm{~km}$ from mainland Vietnam and includes 16 islands and islets with the total land area $76 \mathrm{~km}^{2}$. The weather is characterized by tropical monsoons with direct influence from oceanic climate; the average temperature during the year is $26{ }^{\circ} \mathrm{C}$, the mean humidity: $90 \%$ (Con Dao National Park, 2018).

The Archipelago is composed of magmatic rocks of different ages partially covered by Quaternary marine sediments. The islands are rugged and mountainous, with the highest peak Thanh Gia within the Nui Chua Mountains located on Con Son Island. Thanh Gia Mount reaches $557 \mathrm{~m}$ and the other peaks are of 150-300 m high (Fig. 1, 2A). The island's remoteness and former use as a penal colony have kept it in relatively pristine condition. Even today, $80 \%$ of the largest Con Son Island is still forested. Smaller islands are covered with forestry vegetation to $92 \%$ of their natural area, from the sea level to the highest point of the mountain. Uninhabited islands and part of the Con Son Is. are under protection since 1984 as the Con Dao National Park was enlarged in 1998. Since 2014, the park has been recognized as the 2203rd Ramsar site in the world by UNESCO. The Con Dao National Park covering a total area of 5,998 ha is one of two national parks in Vietnam owing both forest and marine protected area. Protected forest with the total area of around 4,905 ha is dwelled by rich and scanty studied tropical biota presented by rare and endemic for the archipelago species as well. This ecosystem is classified as island tropical forest and is divided into two main types of woods tropical rain closed evergreen forest and tropical rain closed semi-deciduous forest (Hayward, Tran, 2014; Con Dao National Park, 2018).

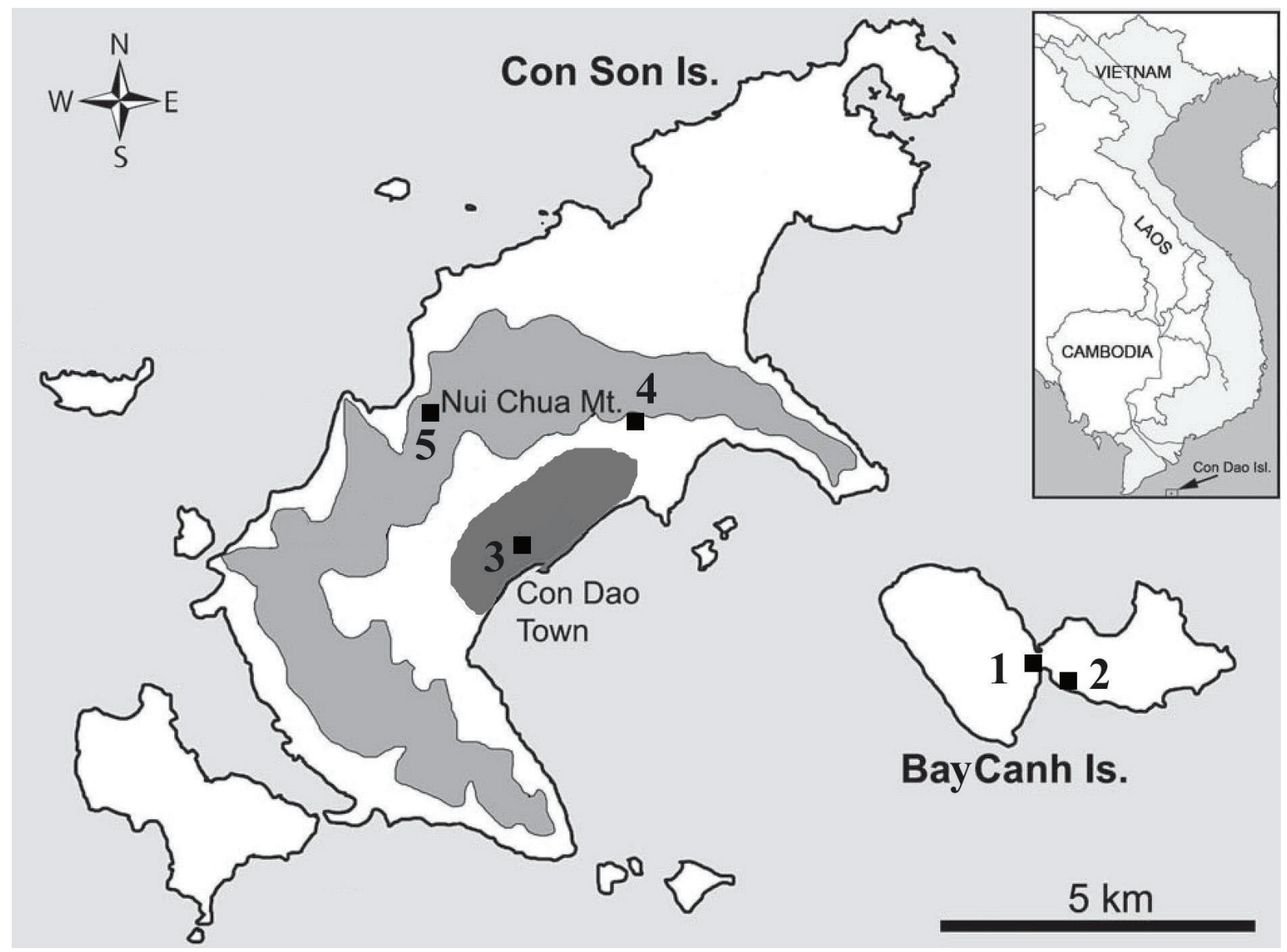

Fig. 1. Map of studied area with five collecting sites on Bay Canh Is. $(1,2)$ and Con Son Is. (3-5) (prepared on the base of illustration from Abramov et al., 2018).

Gray shadings - the main mountain range of the Con Son Island; dark gray shadings - territory of the Con Dao Town. 
Botanic study conducted in 2000 on the archipelago counts 1077 plant species (Le, Tran, 2013). Official report of the biodiversity conservation project with results of biotic inventory of the park (Investigative results ..., 2007) does not include any data on fungi.

Polyporoid and corticioid fungi play an important role in forest ecosystems being the main wood destructors. They are morphological groups of higher basidiomycetes that form fruit bodies with pores or tubes on the underside (polyporoid fungi) or having effused smooth basidiocarps (corticioid fungi). Currently, the polypores are spread among different orders of Agaricomycetes: Polyporales, Hymenochaetales, Corticiales, Gloeophyllales, Russulales, and Trechisporales (Hibbett et al., 2014).

The first checklist of Vietnamese aphyllophoroid fungi including polyporoid and corticioid species
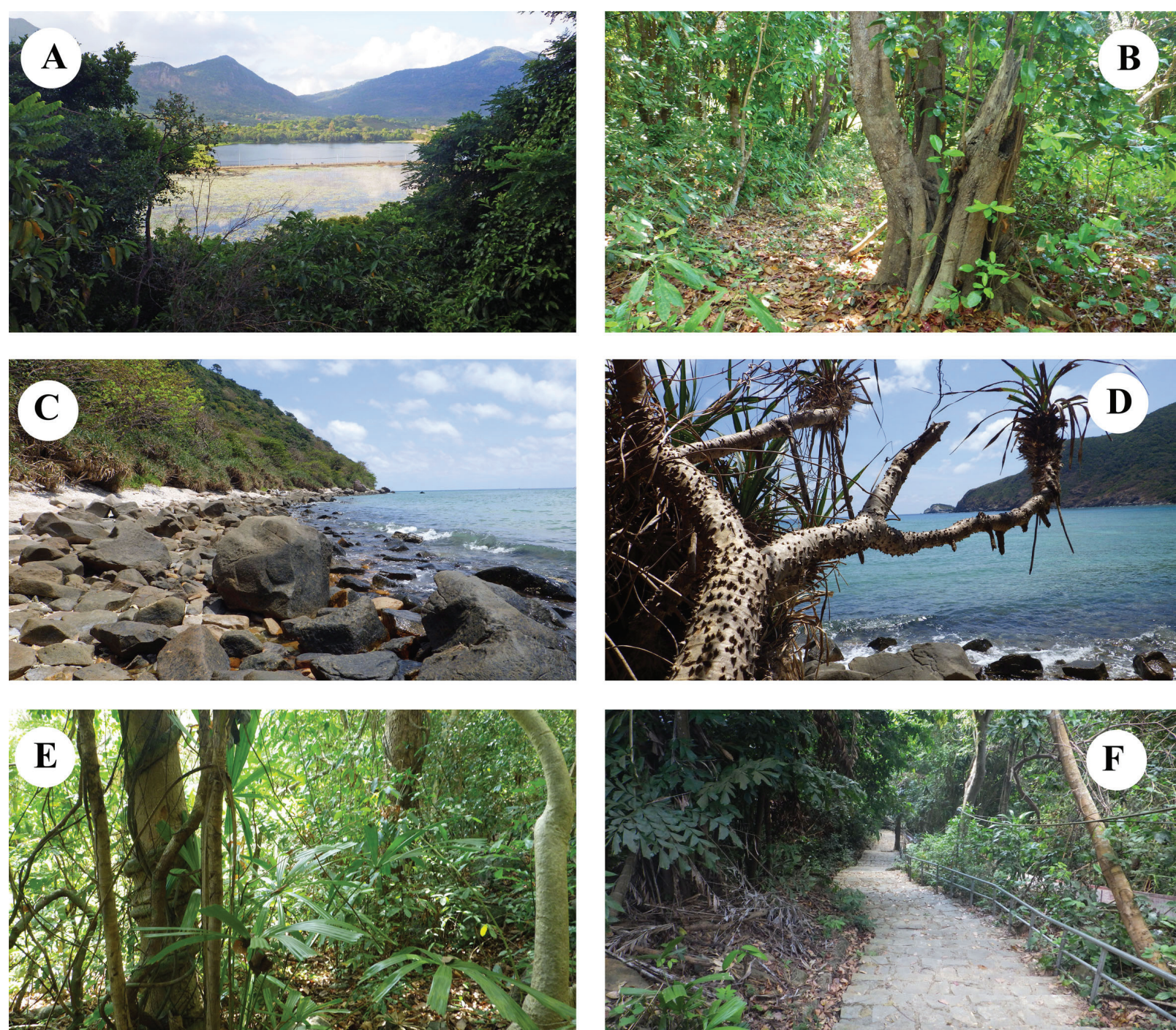

Fig. 2. Landscapes and collecting sites: A - Con Son Is.; B - Bay Canh Is., forest on lowland isthmus near ranger camp; C, D - Bay Canh Is., dry forest on slope of hills along sea coast; E - Con Son Is., dry forest on slope of Nui Chua Mts. in the vicinity of the Con Dao Town; F - Con Son Is., primary mountain forest on the top of Nui Chua Mts. near headquarters of the National Park. 


\section{Materials and methods}

In early March 2019 a short field trip was organized on two largest islands of the archipelago Con Son and Bay Canh with emphasis on mollusks and fungi (Prozorova et al., 2019). Fruit bodies of fungi were collected from deadwood, fallen and dead deciduous tree trunks or branches, as well as stumps, and twigs in these two islands (Fig. 1). Collecting on the territory of the Con Dao National Park was made with official permission of the park management. On March 4 fungi were collected in two sites of fully protected Bay Canh Island. During the period of March 5-8 fungi were harvested in three sites of the Con Son Island under natural conditions and in disturbed area. These five collecting sites were as followings: 1 - Bay Canh Is., forest on lowland isthmus near ranger camp (Fig. 2B); 2 - Bay Canh Is., dry forest on slope of hill near sea coast (Fig. 2C, D); 3 - Con Son Is., Con Dao Town; 4 - Con Son Is., dry forest on slope of Nui Chua Mts. in the vicinity of the Con Dao Town (Fig. 2E); 5 - Con Son Is., primary mountain forest on top of Nui Chua Mts. near headquarters of the National Park (Fig. 2F). As survey was made in period of dry season, all sites were dry or very dry.

Collected specimens are stored in the mycological herbarium of the Federal Scientific Center of the East Asia Terrestrial Biodiversity of Far Eastern Branch of Russian Academy of Sciences, Vladivostok, Russia (VLA). Microscopic identification of species was carried out using a light microscope Olympus CX 31 . The preparations were examined in $10 \% \mathrm{KOH}$ water solution. Samples were determined according to morphological criteria based on modern keys and reference books (Zhao, Zhang, 1992; Núñez, Ryvarden, 2000, 2001; Dai, 2010; Cui et al., 2019).

\section{Results and discussion}

As a result of our study, eight species of polypores and one corticioid fungus (Hymenochaete rubiginosa (Dicks.) Lév.) belonging to eight genera and four families of higher basidiomycetes were identified. Six fungi species were recorded on the Con Son Is. and four species were collected from smaller Bay Canh Is. The classification and nomenclature of fungi are given in accordance with the electronic database "Index Fungorum" (http:// www.indexfungorum.org, 2020).

An annotation for each species indicates its location, habitat, substrate, date of collection, herbarium lot number (VLA), type of rot, distribution, and also links to figures (for some species, the most common synonyms are given in parentheses).

\section{BASIDIOMYCOTA \\ Hymenochaetales \\ Hymenochaetaceae}

Hymenochaete rubiginosa (Dicks.) Lév. (Fig. 3A, 4A) - 06 III 2019, Con Son Is., site 4, VLA M-27154. Causes a white rot of trunks or branches of hardwoods. Cosmopolitan, very common in the tropics as in the boreal or southern hemisphere. The species was recorded in the Central Vietnam before (Trinh, 1998). It is easily recognized macroscopically by its reddish brown or brown to blackish hymenium and microscopically by the presence of a very large layer of densely spaced bristles (Job, 1990; Parmasto, 2001).

Phellinus fastuosus (Lév.) S. Ahmad (Fig. 3B, 4B) - 04 III 2019, Bay Canh Is., site 2, VLA M-27148. Causes a white rot of stumps and fallen trunks of deciduous trees (Bakshi et al., 1970; Corner, 1991). The genus is common in the whole Vietnam (Trinh, 1998; Ngo, Tran, 2011). The species is widespread in the tropical zone (Ryvarden, 2004). In Vietnam it was recorded in its southern part near Nha Trang (Trinh, 1998).

P. gilvus (Schwein.) Pat. (Fig. 3C, 4C) -04 III 2019, Bay Canh Is., site 2, VLA M-27152. Pantropical and in warmer parts of the temperate zone, common in Vietnam (Trinh, 1998). Causes a white rot of dead wood of hardwoods (Gilbertson, 1979).

\section{Polyporales \\ Fomitopsidaceae}

Laetiporus sulphureus (Bull.) Murrill (Fig. 3D, 4D) - 06 III 2019, Con Son Is., site 4, VLA M-27151. Causes a brown rot of fallen trunks and stumps of hardwoods, mainly on oak. It is considered a cosmopolitan species spread from boreal to tropical zones (Ota et al., 2009). Common in Vietnam (Trinh, 1998).

Phanerochaetaceae

Antrodiella serpula (P. Karst.) Spirin et Niemelä [=A. hoehnelii (Bres.) Niemelä] (Fig. 4E) - 05 III 2019, Con Son Is., site 3 (tree in the Con Dao Town), VLA M-27153. Usually found on wood affected by Inonotus radiatus (Sowerby) P. Karst. and on its dead fruiting bodies (Miettinen et al., 2006). Causes a white rot of hardwoods (Job, 1990). This species is known from Europe, Caucasus, Kazakhstan, Japan 
and the South of the Russian Far East (Bondartseva, 1998; Erofeeva, Bukharova, 2018). This is the first record of the species in Vietnam.

\section{Polyporaceae}

Cellulariella acuta (Berk.) Zmitr. et Malysheva [=Lenzites acutus Berk.] (Fig. 3E, 4F) - 06 III 2019, Con Son Is., site 4, VLA M-27147. Causes a white rot of hardwoods, mainly distributed in subtropical to tropical zones (Job, 1990). Common in Vietnam (Trinh, 1998).

Daedaleopsis nitida (Durieu et Mont.) Zmitr. et Malysheva [= Hexagonia nitida Durieu et Mont.] (Fig. 4G) - 06 III 2019, Con Son Is., site 4, VLA M-27155. Causes a white rot in dead Quercus sp., distributed in tropics (Ryvarden, Gilbertson, 1993). This is the first record of the species in Vietnam.

Microporus xanthopus (Fr.) Kuntze (Fig. 3F, 3G, 4H, 4I) - 04 III 2019, Bay Canh Is., site 1, VLA M-27150; 08 III 2019, Con Son Is., site 5, VLA M-27149. Causes a white rot of deciduous wood, often in open habitats. The species is very common throughout the tropics (Ryvarden, Johansen, 1980) including Vietnam, where it is common in forest (Trinh, 1998).

Skeletocutis nivea (Jungh.) Jean Keller (Fig. 3H, 4J) - 04 III 2019, Bay Canh Is., site 1, VLA M-27159. Cosmopolitan white-rot polyporoid species distributed in tropical and temperate zones growing on dead angiosperm wood (Korhonen et al., 2018). This is the first record of the species and the second record of the genus Skeletocutis in Vietnam. Recently S. vietnamensis Rui Du et X.-H. Ji was described from continental part of the country (Du, Ji, 2019).

Six of nine recorded fungi species are widely distributed from boreal zone to tropics - Antrodiella serpula, Skeletocutis nivea, Laetiporus sulphureus, Hymenochaete rubiginosa, Phellinus fastuosus, $P$. gilvus. Other three species are of tropical and subtropical distribution - Daedaleopsis nitida, Cellulariella acuta, Microporus xanthopus. Basidiomycetes Antrodiella serpula (Fig. 4E), Daedaleopsis nitida (Fig. 4G) and Skeletocutis nivea (Fig. 3H, 4J) are probably new for the country. Anyway, we did not find published Vietnamese records of these fungi.

Con Dao wood-inhabiting fungi are most common for pantropics or palaeotropics being associated with tropic tree species. They are characterized by low diversity and wide distribution. Similar situation was revealed on other studied oceanic islands. On the Chagos Archipelago and Seychelles 16 tropic species of polyporoid and corticioid fungi were recorded and none appeared to be distinctive (Watling, Seaward, 2004). The Andaman and Nicobar Islands are larger in area than the Con Dao Archipelago covered by pristine forests as well are inhabited by only 15 non-endemic species of polyporoid and corticoid fungi (Niranjan, Sarma, 2018). Probably, low diversity and wide distribution are common for wood-inhabiting fungi from forested oceanic islands.

All found on Con Dao Islands wood inhabiting fungi belong to the group of xylosaprotrophs destroying wood at different stages of decomposition. Eight species of these polyporoid and corticioid fungi cause the white rot of hardwoods, and one species Laetiporus sulphureus (Fig. 3D, 4D) is agent of the brown rot. White rot fungi cause corrosive decomposition of wood, a characteristic feature of which is that the wood retains some strength and does not grind into powder (Lyubarsky, Vasilyeva, 1975). Lignin-destructive fungi (white rot fungi) are the main group of xylotrophic basidiomycetes, which able to destroy wood slowly but more deeply (Zmitrovich et al., 2007).

Some wood decaying basidiomycetes including these recorded on the Con Dao Islands are of great interest as therapeutically important species (Tura et al., 2016). Many polyporoid fungi are source of the bioactive compounds. For example, Phellinus gilvus (Fig. 3C, 4C) is used for treatment of diseases of the spleen and stomach, to increase immunity, and also has an antitumor effect (Dai, Bau, 2007; Dai, Yang, 2008). Extract of Phellinus fastuosus (Fig. 3B, 4B) can be used as a natural food preservative (Sharifi et al., 2006). Extracts of Laetiporus sulphureus characterized by antioxidant activity might be used in the treatment of endocrine diseases to suppress tumors and increase immunity (Dai, Bau, 2007; Kim et al., 2012). Mycelial extract of fungi from the Laetiporus genus is potential to be used as an anti hypercholesterolemia agent (Aryantha et al., 2010). These facts demonstrate scientific and economic perspectives of further mycological survey on the Con Dao Archipelago.

\section{Acknowledgments}

We would like to thank Eugene S. Popov and Sergey V. Volobuev for providing rare and inaccessible publications on the subject of research. We are very appreciated to management and stuff of the Con Dao National Park for assistance in study of the park biota. 

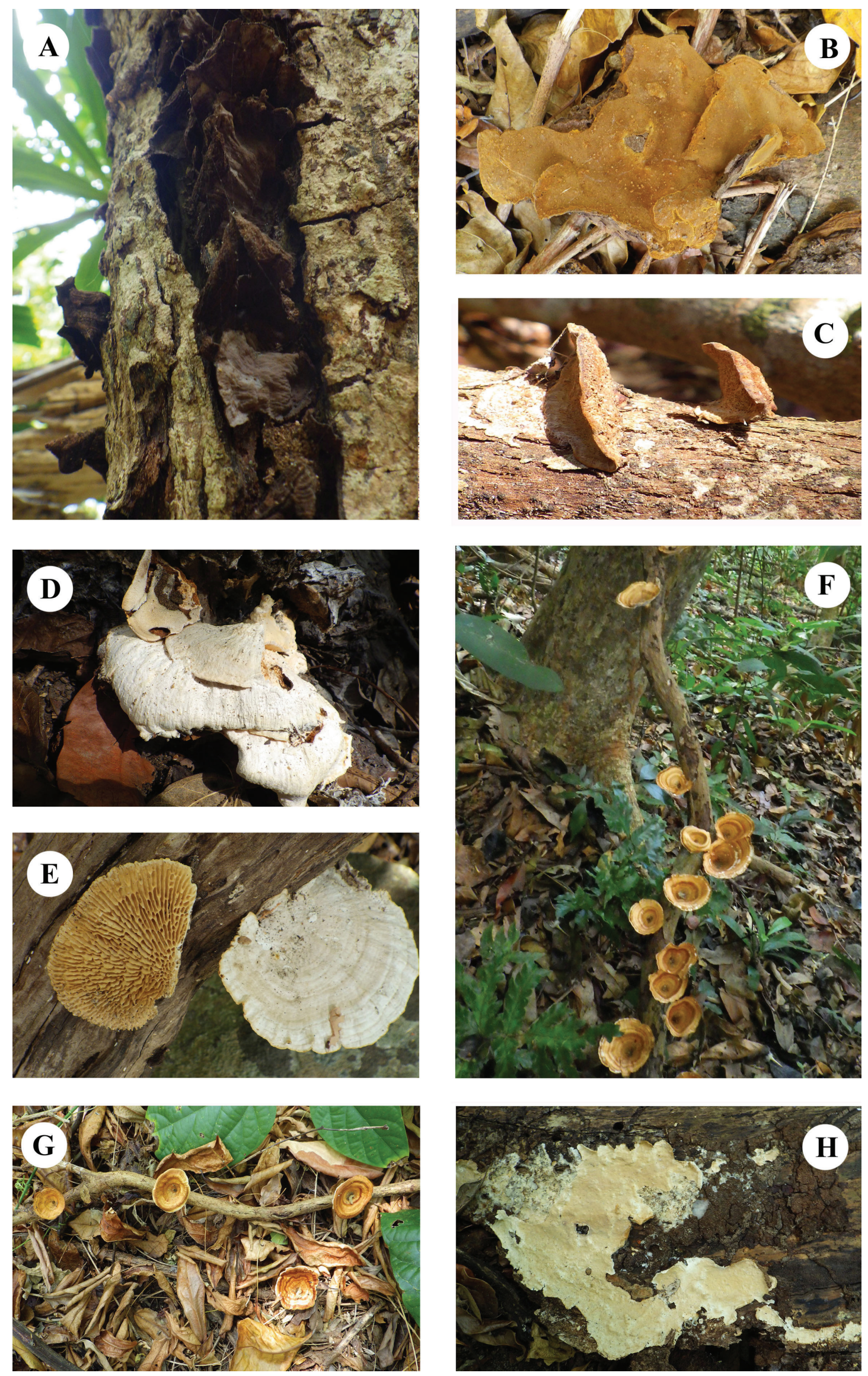

Fig. 3. Seven Con Dao fungi species under natural conditions: A - Hymenochaete rubiginosa; B - Phellinus fastuosus; C - P. gilvus; D - Laetiporus sulphureus; E - Cellulariella acuta; F, G - Microporus xanthopus; H - Skeletocutis nivea. 


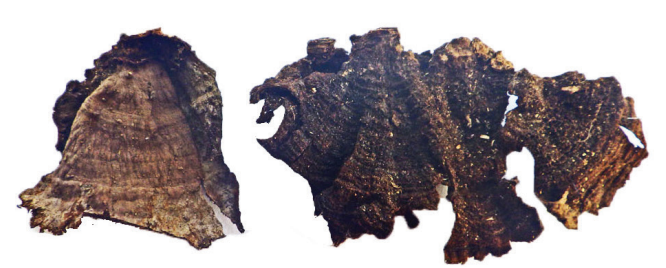

A
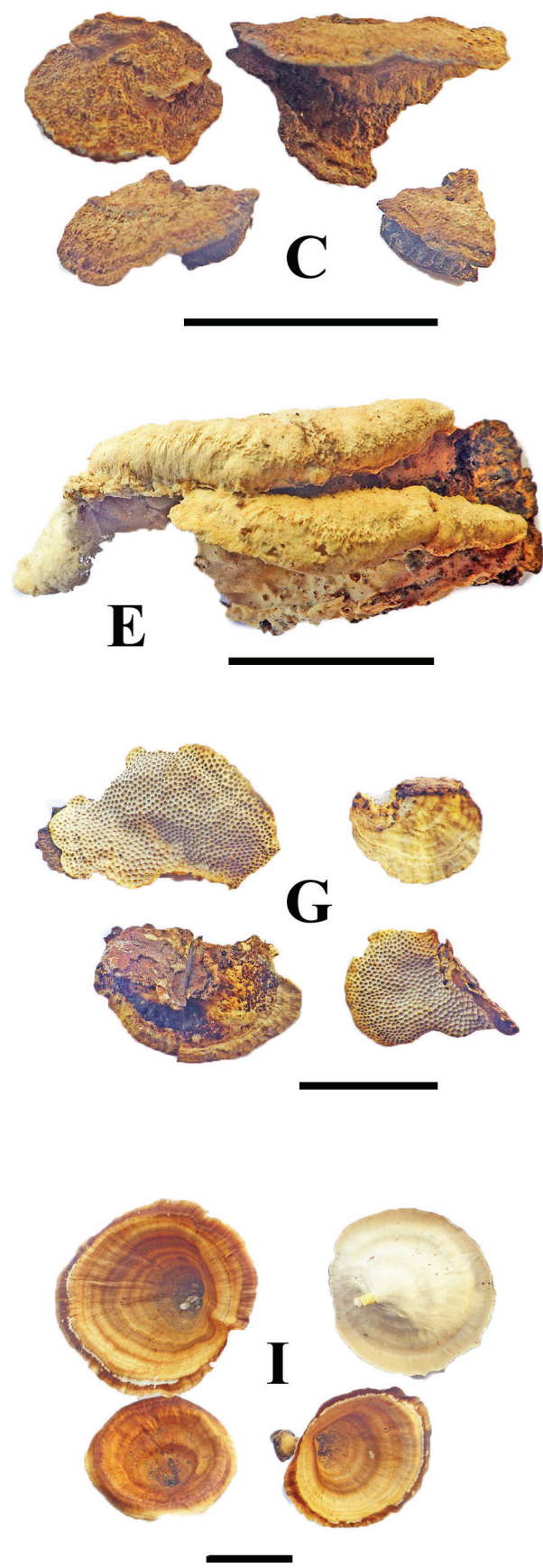
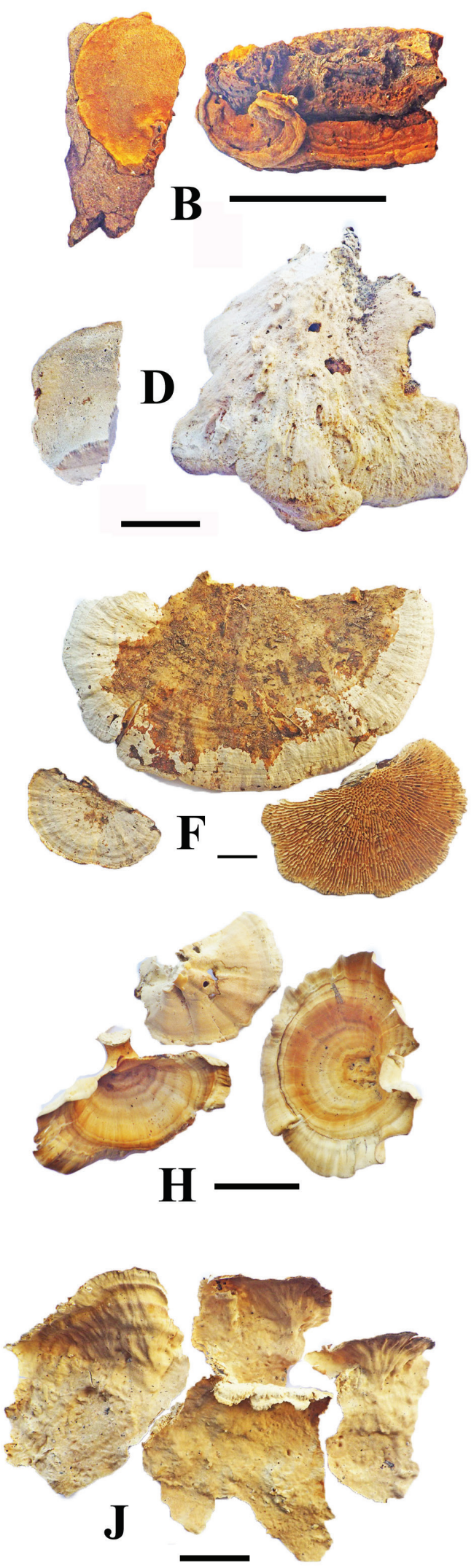

Fig. 4. Con Dao fungi species dried for the VLA mycological herbarium: A - Hymenochaete rubiginosa; B - Phellinus fastuosus; C - P. gilvus; D - Laetiporus sulphureus; E - Antrodiella serpula; $\mathrm{F}$ - Cellulariella acuta; $\mathrm{G}$-Daedaleopsis nitida; H, I - Microporus xanthopus; J - Skeletocutis nivea.

Scale bar $-2 \mathrm{~cm}$. 


\section{REFERENCES}

Abramov A. A., Krushop S. V., Shchinov A. V. 2018. Mammals of Con Son Island, southern Vietnam. Russian Journal of Theriology 17(1): 1-16.

Aryantha I. N. P., Kusmaningati S., Sutjiatmo A. B., Sumartini Y., Nursidah A., Suci Narvikasari S. 2010. The Effect of Laetiporus sp. (Bull. ex Fr.) Bond. et Sing. (Polyporaceae) extract on total blood cholesterol level. Biotechnology 9: 312-318.

Bakshi B. K., Sen M., Singh B. 1970. Cultural diagnosis of Indian Polyporaceae. 2. Genera Fomes and Trametes. Indian Forest Records 2(10): 245-276.

Bondartseva M. A. 1998. Definitorium fungorum Rossiae. Ordo Aphyllophorales. Fasc. 2. Familiae Albatrellaceae, Aporpiaceae, Boletopsidaceae, Bondarzewiaceae, Corticiaceae (species tubuliferae), Fistulinaceae, Ganodermataceae, Lachnocladiaceae (species tubiliferus), Phaeolaceae, Polyporaceae (genera tubuliferae), Poriaceae, Rigidoporaceae. St. Petersburg: Nauka. 391 pp. [In Russian] (Бондарцева М. А. Определитель грибов России. Порядок афиллофоровые. Вып. 2: Семейства альбатрелловые, апорпиевые, болетопсиевые, бондарцевиевые, ганодермовые, кортициевые (виды с порообразным гименофором), лахнокладиевые (виды с трубчатым гименофором), полипоровые (роды с трубчатым гименофором), пориевые, ригидопоровые, феоловые, фистулиновые. СПб.: Наука, 1998. 391 с.).

Con Dao National Park. 2018. URL: http:/www.condaopark.com.vn/en/about.html (Accessed 05 April 2020).

Corner E. J. H. 1989. Ad Polyporaceas VI. The genus Trametes. Beihefte zur Nova Hedwigia 97: 1-197.

Corner E. J. H. 1991. Ad Polyporaceas VII. Beihefte zur Nova Hedwigia 101: 1-175.

Cui B. K., Li H. J., Ji X., Zhou J. L., Song J., Si J., Yang Z. L., Dai Y. C. 2019. Species diversity, taxonomy and phylogeny of Polyporaceae (Basidiomycota) in China. Fungal Diversity 97: 137-392.

Dai Y. C. 2010. Hymenochaetaceae (Basidiomycota) in China. Fungal Diversity 45: 131-343.

Dai Y. C., Bau T. 2007. Illustration of edible and medicinal fungi in Northeastern China. Beijing: Science Press. $232 \mathrm{pp}$.

Dai Y. C., Yang Z. L. 2008. A revised checklist of medicinal fungi in China. Mycosystema 27: 801-824.

Du R., Ji X.-H. 2019. A new species of Skeletocutis (Polyporales, Basidiomycota) from Vietnam. J Microbiol Exp. 7(1): 20-25.

Erofeeva E. A., Bukharova N. V. 2018. First data on aphyllophoroid fungi of the Anyuiskiy National Park (Khabarovsk territory). Mikologiya i fitopatologiya [Mycology and phytopathology] 52(3): 167-173. [In Russian] (Ерофеева $\boldsymbol{E}$. A., Бухарова Н. В. Первые сведения об афиллофороидных грибах национального парка «Анюйский» (Хабаровский край) // Микология и фитопатология, 2018. Т. 52, вып. 3. С. 167-173).

Gilbertson R. L. 1979. The genus Phellinus (Aphyllophorales: Hymenochaetaceae) in western North America. Mycotaxon 9(1): 51-89.

Hayward P., Tran G. T. 2014. At the edge: heritage and tourism development in Vietnam's Con Dao Archipelago. Journal of Marine and Island Cultures 3(2): 113-124.

Hibbet D. S., Bauer R., Binder M., Giachini A. J., Hosaka K., Justo A., Larsson E., Larsson K. Y., Lawrey J. D., Miettinen O., Nagy L. G., Nilsson R. N., Weiss W., Torn R. G. 2014. Agaricomycetes. In: The Mycota. Systematics and evolution. Part A. VII. 2nd ed. Berlin: Springer Verlag. 373-430 pp.

Index Fungorum. 2020. URL: http://www.indexfungorum.org/Names/Names.asp (Accessed 23 March 2020).

Investigative results on valuation of biological potential and marine ecosystems on 700 ha in the Con Dao National Park (report). 2007. Hai Phong: Institute of Marine Environment and Resources VAST. 318 pp.

Job D. J. 1990. Le genre Hymenochaete dans les zones tempérées de l'hémisphère sud. Mycologia Helvetica 4: 1-51. [In French].

Korhonen A., Seelan J. S. S., Miettinen O. 2018. Cryptic species diversity in polypores: the Skeletocutis nivea species complex. Mycokeys 38: 45-82.

Le X. A., Tran D. H. 2013. Conservation of biodiversity resources for sustainable development of Con Dao Island. In: Proceeding of the 5th National Science Conference of Ecology and Biological Resources. Hanoi: Agriculture Publishing House. Pp. 355-359. [In Vietnamese] (Lê Xuan Ai, Trần Đinh Hue. Bảo tồn tài nguyên đa dạng sinh học cho sự phát triển bền vững Côn Đảo: Báo cáo Khoa học về sinh thái và tài nguyên sinh - Hội nghị Khoa học toàn quốc lần thứ năm. Hà Nội: Nxb Nông nghiệp. 2013. Tr. 355-359).

Lyubarsky L. V., Vasilyeva L. N. 1975. Derevorazrushayushchie griby Dal'nego Vostoka [Wood-destroying fungi of the Far East]. Novosibirsk: Nauka. 164 pp. [In Russian] (Любарский Л. В., Васильева Л. Н. Дереворазрушающие грибы Дальнего Востока. Новосибирск: Наука, 1975. 164 с.).

Miettinen O., Niemelä T., Spirin W. 2006. Northern Antrodiella species: the identity of A. semisupina, and type studies of related taxa. Mycotaxon 96: 211-239.

Ngo A., Tran T. B. 2011. Study of the macromycoflora in Xuyen Moc District, Ba Ria - Vung Tao Province. Hanoi. Pp. 37-43. [In Vietnamese] (Ngo Anh, Trần Thị Bích Thủy. 2011. Nghiên cứu khu hệ nấm lớn ở huyện Xuyên 
Mộc,tỉnh Bà Rịa - Vũng Tàu. Hội nghị khoa học toàn quốc về sinh thái và tài nguyên sinh vật lần thứ 4 . Ha Noi. Pp. 37-43).

Niranjan M., Sarma V. V. 2018. A check-list of fungi from Andaman and Nicobar Islands, India. Phytotaxa 347(2): 101-126.

Núñez M., Ryvarden L. 2000. East Asian Polypores. Vol. 1. Ganodermataceae and Hymenochaetaceae. Synopsis Fungorum 13: 1-169.

Núñez M., Ryvarden L. 2001. East Asian Polypores. Vol. 2. Polyporaceae s. 1. Synopsis Fungorum 14: 170-522.

Ota Y., Hattori T., Banik M. T., Hagedorn G., Sotome K., Tokuda S., Abe Y. 2009. The genus Laetiporus (Basidiomycota, Polyporales) in East Asia. Mycological Research 113: 1283-1300. DOI: 10.1016/j.mycres.2009.08.014

Parmasto E. 1986. Preliminary list of Vietnamese Aphyllophorales and Polyporaceae s. str. Scripta Mycol. 14: $1-88$.

Parmasto E. 2001. Hymenochaetoid fungi (Basidiomycota) of North America. Mycotaxon 79: 107-176.

Pham T. H., Popov E. S., Morozova O. V., Nguyen D. H. 2018. Basidiomycetous Macromycetes of the Tay Nguyen Plateau in Vietnam: The History of Investigation. Mikologiya i fitopatologiya [Mycology and phytopathology] 52(5): 306-318. [In Russian] (Фам Тхи Ха Жанг, Попов Е. С., Морозова О. В., Нгуен Данг Хой. История изучения базидиальных макромицетов Центрального нагорья Вьетнама // Микология и фитопатология, 2018. T. 52, № 5. C. 306-318).

Prozorova L. A., Ngo X. Q., Ternovenko V. A. 2019. Aquatic and terrestrial mollusks of the Con Dao Archipelago (southern Vietnam): first result of malacological survey in March 2019. In: Abstracts of the International Seminar on biodiversity and evolution of mollusks (September 26-27, 2019, Vladivostok, Russia). Vladivostok: NSCMB FEB RAS and RFEMS. Pp. 58-59.

Ryvarden L. 2004. Neotropical Polypores. Part 1. Introduction, Hymenochaetaceae and Ganodermataceae. Synopsis Fungorum 19: 1-227.

Ryvarden L., Gilbertson R. L. 1993. European polypores. Part 1. Synopsis Fungorum 6: 1-387

Ryvarden L., Johansen I. 1980. A preliminary polypore flora of East Africa. Oslo: Fungiflora. $636 \mathrm{pp}$.

Sharifi A., Bhosle S. R., Vaidya J. G. 2006. Evaluation of crude sesquiterpenoid extract of Phellinus fastuosus as a natural preservative. Hindustan antibiotics bulletin 47-48(1-4): 20-30.

Trinh T. K. 1998. Preliminary checklist of macrofungi of Vietnam. Feddes Repertorium 109(3-4): 257-277.

Trinh T. K. 2011. Macrofungi of Vietnam. Vol. 1. Hanoi: Natural Science and Technology Publishing House. 314 pp. [In Vietnamese] (Trịnh Tam Kiet. 2011. Nấm lớn ở Viet Nam (tập 1). Hà Nội: NXB Khoa học tự nhiên và công ngh. 314 pp.).

Trinh T. K. 2012. Macrofungi of Vietnam. Vol. 2. Hanoi: Natural Science and Technology Publishing House. 413 pp. [In Vietnamese] (Trịnh Tam Kiet. 2012. Nấm lớn ở Viet Nam (tập 2). Hà Nôi: Khoa hoc và ky thuat. 413 pp.).

Tura D., Zmitrovich I. V., Wasser S. P. 2016. Wood-inhabiting fungi: Applied aspects. In: Fungi: Applications and management strategies. London; New York etc.: CRC Press. Pp. 245-292.

Watling R., Seaward M. R. D. 2004. Some fungi of Indian Ocean Islands. Botanical Journal of Scotland 56(1): 65-84. DOI: $10.1080 / 03746600408685068$

Yurchenko E., Wu S. H. 2012. New records of Hyphodontia sphaerospora in Taiwan and Vietnam. Fungal Science 27: 9-15.

Zhao J. D., Zhang X. Q. 1992. The Polypores of China. Bibliotheca Mycologica 145: 1-524.

Zmitrovich I. V., Psurtseva N. V., Belova N. V. 2007. Evolutionary and taxonomical aspects of search and study of lignin-degrading fungi - active producers of oxidative enzymes. Mikologiya i fitopatologiya [Mycology and phytopathology] 41(1): 57-78. [In Russian] (3митрович И. В., Псурцева Н. В., Белова Н. В. Эволюционно-таксономические аспекты поиска и изучения лигнинразрушающих грибов - активных продуцентов окислительных ферментов // Микология и фитопатология. 2007. Т. 41, вып. 1. С. 57-78). 